\title{
The state of climate change research in Swiss protected areas
}

\author{
Emiliano Tolusso
}

Keywords: geography of science, protected areas, Switzerland, climate change research, epistemic communities, research networks

\section{Abstract}

Climate change is a scientific topic rarely addressed in Swiss protected areas. Starting from a survey of the spatial distribution of research projects addressing climate change in protected areas derived from Parkforschung.ch data, this report highlights some of the main issues that climate change science is facing in developing research interest in the field. The sources of information are expert interviews carried on during 2018.

\section{Preliminary remarks on the geography of scientific interest and the role of experts}

Despite its relatively young age, Switzerland's system of protected areas (PAs) benefits from a notable collection of research records. Topics ranging from the acceptance of PAs by local populations to specific ecological issues are addressed and stored in a thematic catalogue. However, despite being discussed frequently in both science and policy domains, the topic of climate change is seldom addressed as a research theme in PAs (Table 1).

In order to shed light on this peculiar situation, a set of semi-structured interviews was organized between January and June 2018. The research design was informed by the notion of epistemic community, defined as a "group of professionals, often from a variety of different disciplines, which produce policy-relevant knowledge about complex technical issues" (Haas 1992, 16). This framework is intended as a way not only to counter data scarcity but also to understand how policy and management-relevant knowledge is formed and how members of the community interact with it. If "ideas would be sterile without carriers" (Haas 1992, 27), then policies and scientific research - or the lack thereof - can be better understood in their complexity by adopting the standpoints of a variety of different actors. This claim proves especially true in the case of conservation, where communities are formed by an assemblage of scientists, practitioners, managers and policymakers (Lorimer 2015). With the purpose of pursuing this goal, the interviewees in our study were initially selected with the help of two experts on research in PAs from the Swiss Academy of Natural Science (ScNat). Those selected were then divided into four groups (Table 2): (1) scientists currently (or in the recent past) conducting a research project on climate change in PAs; (2) research coordinators or members of a research council; (3) conservationists or administrative managers; (4) external social or natural scientists with a particular perspective on, and expertise in, the issue addressed.

Expert interviews helped to define some possible explanations for the relative lack of research projects on the topic of climate change in Swiss PAs and to make sense of the scattered geographical pattern that emerged from the available data. Presenting the main topics arising from the interviews, this report is in several sections examining specific points of interest. However, these points should not be considered discrete and independent, but precisely the opposite. Management and scientific issues are intertwined and indeed very difficult to separate. Hence the reader should not be surprised to find resonance between points. Note that the considerations presented here represent the preliminary results of a more extensive analysis.

\section{Some obstacles at the science-management interface}

With the notable exception of the Swiss National Park, Swiss PAs tend to be reactive rather than proactive with regard to climate change monitoring. The most evident indicator of this scientific and management attitude can be seen in the fact that if climate change does not affect - or strongly threaten to affect - some of the conservation objects or goals of an individual PA, or if it is not even addressed by a particular research policy within the PA, the PA's management do not dedicate any research to the subject.

As the interviews highlight, when heavy economic, social and political structures like PAs allocate interest, funding and human resources to a research project, they seldom do so without concrete evidence of a threat towards their core interests. In particular, the young age of the majority of Swiss PAs forces them to focus on monitoring acceptance by local populations, and the effectiveness of their conservation and sustainable development practices. As a direct consequence, Swiss PAs display a rather low rate of participation in international monitoring endeavours in the field of climate change. Even when they are already empirically facing some degree of change, there is a tendency by the PA's administration to see this as tolerable, as a phenomenon to be addressed in the future. This attitude is mostly explained by the need to ad- 
Table 1 - Research records divided by PAs and research typology. Source: Parkforschung Schweiz.

\begin{tabular}{|c|c|c|c|c|c|c|c|}
\hline & \begin{tabular}{|l|} 
Total \\
research \\
records \\
\end{tabular} & $\begin{array}{l}\text { Research } \\
\text { projects }\end{array}$ & $\begin{array}{l}\text { Management- } \\
\text { oriented } \\
\text { projects }\end{array}$ & $\begin{array}{l}\text { Permanent/ } \\
\text { Monitoring } \\
\text { projects }\end{array}$ & Dissertations & Masters & Bachelors \\
\hline Regional Nature Park Beverin & 0 & 0 & 0 & 0 & 0 & 0 & 0 \\
\hline Regional Nature Park Binntal & 0 & 0 & 0 & 0 & 0 & 0 & 0 \\
\hline Regional Nature Park Biosfera Val Mustair & 5 & 3 & 1 & 0 & 0 & 1 & 0 \\
\hline Regional Nature Park Chasseral & 0 & 0 & 0 & 0 & 0 & 0 & 0 \\
\hline Regional Nature Park Diemtigtal & 0 & 0 & 0 & 0 & 0 & 0 & 0 \\
\hline Regional Nature Park Doubs & 0 & 0 & 0 & 0 & 0 & 0 & 0 \\
\hline Regional Nature Park & 0 & 0 & 0 & 0 & 0 & 0 & 0 \\
\hline Regional Nature Park Gantrisch & 0 & 0 & 0 & 0 & 0 & 0 & 0 \\
\hline Regional Nature Park Gruyère Pays-d'Enhaut & 1 & 1 & 0 & 0 & 0 & 0 & 0 \\
\hline Regional Nature Park Jura Vaudois & 1 & 1 & 0 & 0 & 0 & 0 & 0 \\
\hline Regional Nature Park Jurapark Aargau & 0 & 0 & 0 & 0 & 0 & 0 & 0 \\
\hline Regional Nature Park Pfyn-Finges & 1 & 0 & 0 & 0 & 1 & 0 & 0 \\
\hline Regional Nature Park Schaffhausen & 0 & 0 & 0 & 0 & 0 & 0 & 0 \\
\hline Regional Nature Park Thal & 0 & 0 & 0 & 0 & 0 & 0 & 0 \\
\hline $\begin{array}{l}\text { Swiss Alps Jungfrau-Aletsch UNESCO World } \\
\text { Heritage }\end{array}$ & 3 & 0 & 0 & 0 & 0 & 2 & 1 \\
\hline Swiss National Park & 13 & 4 & 0 & 3 & 2 & 4 & 0 \\
\hline $\begin{array}{l}\text { Swiss Tectonic Arena Sardona UNESCO } \\
\text { World Heritage }\end{array}$ & 1 & 0 & 1 & 0 & 0 & 0 & 0 \\
\hline UNESCO Biosphere Entlebuch & 3 & 2 & 0 & 0 & 0 & 1 & 0 \\
\hline $\begin{array}{l}\text { UNESCO Biosphärenreservat Engiadina Val } \\
\text { Müstair }\end{array}$ & 1 & 1 & 0 & 0 & 0 & 0 & 0 \\
\hline Wildnispark Zurich & 1 & 1 & 0 & 0 & 0 & 0 & 0 \\
\hline Total & 30 & 13 & 2 & 3 & 3 & 8 & 1 \\
\hline
\end{tabular}

dress more pressing issues regarding land use, landowning rights, and land concessions. Even if signs of changes in the composition of an ecosystem might be empirically detectable, their relatively low current impact is preventing the formation of keen interest. Moreover, a considerable number of researchers and research coordinators remarked on the high resilience of mountain ecosystems, which are not yet showing evidence of substantial changes.

Additionally, some interviewees belonging to categories 2 and 3 highlighted how the physical ability to cope with changes (or the absence of such an ability) is influencing research. Scientific endeavours in PAs ought to include the dimension of applied research. The retreat of a glacier or the upward migration of a particular species, for example, are not perceived as phenomena that can be managed or controlled, and they (probably) do not pose any threat to the integrity of the PA in terms of its natural heritage and infrastructure. By contrast, an increase in the number or intensity of wildfires might be perceived as a physical threat to both. Given the low density of research distribution in the PA system, it is probably safe to assume that climate change is not yet seen as a physical threat to the infrastructure of PAs or to ecosystems.

In relation to this last claim, interviews showed a reasonable degree of agreement around the need to gather more information describing the effects of climate change on ecosystems, in order for adaptation measures to be taken. As some interviewees highlighted, there is no evidence available to demonstrate substantial influences of climate change on the struc- ture and function of ecosystems. Hence it is crucial to stimulate new basic research on these topics, in order to enhance the ability to detect actual threats to ecosystems that are deemed worthy of legal protection. This fact resonates with a broader struggle of climate science - to spread effectively the concept of scientific uncertainty within political and administrative domains.

\section{Factors hindering research by the scientific community}

From the point of view of science, the task of organizing and conducting climate change research poses significant challenges. Most of the interviewees belonging to categories 1 and 2 highlighted how the absence of historical series of data constitutes an obstacle for monitoring the development of climate change and its physical and ecological consequences. This is especially true in young PAs, where scientific endeavours might be entirely new. From springs to moorlands, ecological monitoring initiatives suffer from the lack of reference data gathered in the past.

Another set of problems addressed in the interviews is directly linked to the problem of scientific uncertainty. Models describing the spatiotemporal evolution of environmental variables are not always available, and even when they are, it can be difficult to provide plausible answers to the questions initially posed. The case of Entlebuch's moorlands epitomizes both kinds of scientific problems, since it both lacks historical data series on the evolution of moorland 
Table 2 - Interviewees grouped by category and institutional affiliation

\begin{tabular}{|l|r|l|}
\hline Categories & Number & Institutions \\
\hline Scientists conducting research projects & 3 & University of Bern, University of Zurich, University of Basel \\
\hline Research coordinators/members of research councils & 2 & UNESCO Biosphere Entlebuch, Swiss National Park \\
\hline Conservationists/Park Managers & 1 & ProNatura \\
\hline $\begin{array}{l}\text { Social/natural scientists involved in conservation or climate change } \\
\text { research }\end{array}$ & 4 & University of Innsbruck, ProClim, WSL \\
\hline
\end{tabular}

ecosystems and deals with the uncertainty of the future progression of climate change and of its effects, which do not necessarily display a clear relationship.

Critical consideration of the spatial and temporal necessities of a hypothetical climate change research project led some of the interviewees to advance the hypothesis of a mismatch in scale between the problems related to climate change and the inquiry capabilities of PAs, in relation both to time and to space. The absence of historical data means that the acquisition of useful information could take decades to show meaningful trends, and the limited geographical scope of the PAs might not be an ideal setting to monitor the development of ecological changes.

The result of such a combination of limiting factors is the limited amount of background research available for climate change research and monitoring in almost every PA.

\section{The Swiss National Park: an exception to the rule}

Against this background, the Swiss National Park stands out as an exception to the general rule for several reasons. The PA has historically conducted research that includes climate change as a variable of interest, in relation not just to a particular ecosystem, species or disturbance, but also to ecosystem changes more generally. Moreover, given the primacy of science within the perimeter of the Park, any alteration caused by climate change is not to be considered a failing in relation to the specific conservation goals of the PA, but rather an opportunity to study the ecological dynamics of climate change without human intervention.

The deep historical roots of the Swiss National Park have a direct positive influence on the possibilities of inquiry. Moreover, by virtue of the abundance of historical scientific observations, the National Park is in a position to study climate change effectively by repeating older surveys on plant and animal distribution within its boundaries.

From an international cooperation standpoint, the Swiss National Park displays signs of differing substantially from its wider geographical region. The NP is, in fact, a fundamental part of international monitoring networks focusing on the effects of climate change, as in the GLORIA programme (https://www. gloria.ac.at/), and GLOCHAMOST (http://www. unesco.org/new/en/natural-sciences/environment/ ecological-sciences/specific-ecosystems/mountains/ glochamost/). Additionally, interviews highlight that the Park is in contact with other, geographically smaller ecological monitoring networks, such as Lacs sentinelles or Spring Monitoring. It is also an integral part of wildlife monitoring programmes that can be instrumental in assessments of the impacts of climate change.

These considerations led climate change to be included among the primary research directions for the period 2008-2018. However, there is no sign yet of a concerted research programme on the subject.

\section{The role of International scientific monitor- ing programmes in the future of climate change research}

Even if data scarcity is an unavoidable obstacle, because the temporal gap in data collection cannot be filled, PAs might be able to serve as climate change observatories if they were involved in broader monitoring projects. When questioned on the future role of international scientific cooperation in promoting climate change research, interviewees from categories 2 and 4 agreed in principle on the projected centrality of international cooperation, but highlighted two aspects deemed crucial in order to increase the number of studies on the topic, one being purely scientific, and the other related to the policies and practice of ecosystem conservation.

First, international research endeavours have to be designed and conducted in a way that can generate new research in the PAs involved, following, for instance, the blueprint of GLORIA's ancillary projects designed in the Swiss National Park. International research projects should act as an umbrella under which new parallel projects can be organized and conducted. Following this approach, the lack of historical observations and data might be overcome by a wider spatial dimension that opens up the possibility of data comparisons between different geographical areas and integrates the research protocol with new observations from outside existing international research schemes.

Second, especially in PAs where science is not at the core of conservation programmes, or where it shares a central role with local sustainable development goals, research can be translated into effective conservation practices only if accompanied by mechanisms that allow the allocation of resources to all the stakeholders, including private landowners, with the ultimate aim of conserving endangered, rare or highly-valued ecosys- 
tems from the threat that climate change might pose in the foreseeable future. In this perspective, the future development of research projects could be dependent on creating conservation interest among all the stakeholders with regard to climate-sensitive ecosystems, landscapes and habitats.

\section{Conclusions}

From the analysis of the causes of the particular spatial distribution of studies on the effects of climate change in PAs, Switzerland's PA system emerges as a very heterogeneous case. Parks and other protected areas aim to protect different objects and pursue different goals, and not all of them have either the capacity to engage with climate change as a topic worthy of scientific enquiry, or an interest in doing so. But even when they do engage with the subject, administrative contingencies, other pressing scientific questions, and the limited history of scientific research might represent obstacles to a successful engagement by the scientific community. Nevertheless, climate research might find a way into Swiss PAs' research interests via international multi-site monitoring initiatives, but only under scientific conditions that are able to stimulate autonomous integrative research, and administrative conditions able to link scientific interest in climate change with the sustainable management of the PAs' valued resources.

\section{References}

Lorimer, J. 2015, Wildlife in the Anthropocene. Minneapolis

Haas, P. 1992, Epistemic communities and international policy coordination. International Organization 46 (1): $1-35$.

\section{Author}

\section{Emiliano Tolusso}

is a $\mathrm{PhD}$ candidate in environmental geography at the University of Milan. He is part of the Doctoral School of Philosophy and Human Sciences, where he is conducting a project that maps research activities on climate change in alpine protected areas. Università degli Studi di Milano. Via Festa del Perdono 7, 20122 Milano. E-mail: emiliano.tolusso@unimi.it

Table 3 - Every research record on climate and climate change archived in the database. Source: Parkforschung Schweiz.

\begin{tabular}{|c|c|c|c|c|}
\hline Protected Area & $\begin{array}{l}\text { Research } \\
\text { records }\end{array}$ & Research title & Publications & $\begin{array}{l}\text { Principal } \\
\text { investigator }\end{array}$ \\
\hline \multirow[t]{5}{*}{$\begin{array}{l}\text { Regional Nature Park Bios- } \\
\text { fera Val Mustair }\end{array}$} & \multirow[t]{5}{*}{5} & $\begin{array}{l}\text { Impacts of climate change on the tourism business in the } \\
\text { winter season in the Swiss National Park region }\end{array}$ & $\begin{array}{l}\text { 1) Stan, V. 2016. Climate change in the Swiss National Park region: } \\
\text { Impacts of climate change on the tourism business in winter season in } \\
\text { the Swiss National Park region. Masterthesis, HTW Chur. }\end{array}$ & Nikitin, Ivan \\
\hline & & $\begin{array}{l}\text { Empfindlichkeit von Quell-Lebensgemeinschaften ge- } \\
\text { genüber Klimaveränderungen in den Alpen }\end{array}$ & $\begin{array}{l}\text { 1) Küry, D., V. Lubini \& P. Stucki 2016. Temperature patterns and } \\
\text { factors governing thermal response in high elevation springs of } \\
\text { the Swiss Central Alps. Hydrobiologia DOI 10.1007/s10750-016- } \\
2918-0 \text {. } \\
\text { 2) Küry, D., V. Lubini \& P. Stucki. Empfindlichkeit von Quell-Leb- } \\
\text { ensgemeinschaften gegenüber Klimaveränderungen in den Alpen. } \\
\text { Projekt-Schlussbericht. }\end{array}$ & Küry, Daniel \\
\hline & & $\begin{array}{l}\text { Klima- und Bestandesgeschichte im Arvenurwald God da } \\
\text { Tamangur }\end{array}$ & Not available & Stoffel, Markus \\
\hline & & $\begin{array}{l}\text { Prognostizierte Effekte des Klimawandels auf Indika- } \\
\text { torarten für strukturelle und biologische Diversität im } \\
\text { Gebirgswald }\end{array}$ & Not available & Bollmann, Kurt \\
\hline & & $\begin{array}{l}\text { Wie wirkt sich der Klimawandel auf die Verbreitung des } \\
\text { Schneehasen (Lepus timidus) in klimatisch unterschiedli- } \\
\text { chen Regionen der Schweiz aus? }\end{array}$ & Not available & Rehnus, Maik \\
\hline $\begin{array}{l}\text { Regional Nature Park } \\
\text { Gruyère Pays-d'Enhaut }\end{array}$ & 1 & Les narcisses et le réchauffement climatique & Not available & $\begin{array}{l}\text { Randine, } \\
\text { Cristophe }\end{array}$ \\
\hline $\begin{array}{l}\text { Regional Nature Park Jura } \\
\text { Vaudois }\end{array}$ & 1 & $\begin{array}{l}\text { MOUNTLAND - Impact des Changements de Gestion et } \\
\text { des Changements Climatiques sur les Pâturages Boisés } \\
\text { d'altitude }\end{array}$ & Not available & $\begin{array}{l}\text { Buttler, Alex- } \\
\text { andre }\end{array}$ \\
\hline $\begin{array}{l}\text { Regional Nature Park Pfyn- } \\
\text { Finges }\end{array}$ & 1 & $\begin{array}{l}\text { Record of Past Environmental and Climatic Changes in } \\
\text { the Sediment Record of Lake Pfafforet (Valais, Switzerland) }\end{array}$ & $\begin{array}{l}\text { 1) Straub, M. 2008. Record of Past Environmental and Climatic } \\
\text { Changes in the Sediment Record of Lake Pfafforet. Diplomarbeit, } \\
\text { ETH Zürich. } \\
\text { 2) Straub, M., F. Anselmetti \& L. Wick. Die Sedimente des Pfafforet- } \\
\text { sees (Pfynwald). archaeologia vallesiana } 4 .\end{array}$ & $\begin{array}{l}\text { Anselmetti, } \\
\text { Flavio }\end{array}$ \\
\hline
\end{tabular}




\begin{tabular}{|c|c|c|c|c|}
\hline Protected Area & \begin{tabular}{|l} 
Research \\
records
\end{tabular} & Research title & Publications & $\begin{array}{l}\text { Principal } \\
\text { investigator }\end{array}$ \\
\hline \multirow[t]{3}{*}{$\begin{array}{l}\text { Swiss Alps Jungfrau-Aletsch } \\
\text { UNESCO World Heritage }\end{array}$} & \multirow[t]{3}{*}{3} & $\begin{array}{l}\text { Contributions to the knowledge of alpine bird communi- } \\
\text { ties with special reference to the climatic constraints }\end{array}$ & $\begin{array}{l}\text { 1) Frey, M. 1989. Brutbiologie des Hänflings unter den Einflüssen des } \\
\text { Gebirgsklimas. Ornithologische Beobachtungen 86: 265-289. } \\
\text { 2) Glutz von Blotzheim, U. 1966. Handbuch der Vögel Mitteleuropas. } \\
\text { Wiesbaden. } \\
\text { 3) Glutz von Blotzheim, U. 1987. Verbreitung, Siedlungsdichte und } \\
\text { Brutbiologie der Vögel des Urserentales, insbesondere der Lorbeer- } \\
\text { weiden-Gesellschaft zwischen Realp und Hospental. Ornithologische } \\
\text { Beobachtungen 84: 249-274. } \\
\text { 4) Glutz von Blotzheim, U. 1990. Avifauna von Windwurfflächen } \\
\text { (Sturmschadenflächen) im Tannen- Buchenwaldareal am Schwyzer } \\
\text { Nordalpenrand. Typoskript. } \\
\text { 5) Glutz von Blotzheim, U. 1992. Avifauna des Obergoms, insbeson- } \\
\text { dere des Rhonegletschervorfeldes. Typoskript. } \\
\text { 6) Heiniger, Ph.H. 1991. Anpassungsstrategien des Schnefinkren an } \\
\text { die extremen Umweltbedingungen des Hochgebirges. Ornithologis- } \\
\text { che Beobachtungen 88: 193-207. } \\
\text { 7) Luder, R. 1993. Vogelbestände und -lebensräume in der Ge- } \\
\text { meinde Lenk (Berner Oberland): Veränderungen im Laufe von } 12 \\
\text { Jahren. Ornithologische Beobachtungen 90: 1-34. } \\
\text { 8) Schaffner, U. 1990. Die Avifauna des Naturwaldreservates } \\
\text { Combe-Grède. Ornithologische Beobachtungen 87: 107-129. }\end{array}$ & Glutz, Urs \\
\hline & & $\begin{array}{l}\text { Stakeholder Responses to Climate Change in the Swiss } \\
\text { Alps }\end{array}$ & $\begin{array}{l}\text { Hill, M., A. Wallner \& J. Furtado 2010. Reducing vulnerability to cli- } \\
\text { mate change in the Swiss Alps: a study of adaptive planning. Climate } \\
\text { Policy 10: 70-86. }\end{array}$ & Wallner, Astrid \\
\hline & & $\begin{array}{l}\text { Klimabedingte Veränderung des saisonalen Abflussverh- } \\
\text { altens alpiner Einzugsgebiete in dern Schweizer Alpen und } \\
\text { Südalpen Neuseelands }\end{array}$ & $\begin{array}{l}\text { Studer, C. 2014. Klimabedingte Veränderung des saisonalen } \\
\text { Abflussverhaltens alpiner Einzugsgebiete in dern Schweizer Alpen und } \\
\text { Südalpen Neuseelands. Masterarbeit, Universität Bern. }\end{array}$ & $\begin{array}{l}\text { Weingartner, } \\
\text { Rolf }\end{array}$ \\
\hline \multirow[t]{10}{*}{ Swiss National Park } & \multirow{10}{*}{$\begin{array}{l}13(+2 \\
\text { elder } \\
\text { climate } \\
\text { monitor- } \\
\text { ing, in } \\
\text { bold) }\end{array}$} & $\begin{array}{l}\text { Impacts of climate change on the tourism business in the } \\
\text { winter season in the Swiss National Park region }\end{array}$ & $\begin{array}{l}\text { 1) Stan, V. 2016. Climate change in the Swiss National Park region: } \\
\text { Impacts of climate change on the tourism business in winter season in } \\
\text { the Swiss National Park region. Masterthesis, HTW Chur. }\end{array}$ & Nikitin, Ivan \\
\hline & & $\begin{array}{l}\text { Empfindlichkeit von Quell-Lebensgemeinschaften ge- } \\
\text { genüber Klimaveränderungen in den Alpen }\end{array}$ & $\begin{array}{l}\text { 1) Küry, D., V. Lubini \& P. Stucki 2016. Temperature patterns and } \\
\text { factors governing thermal response in high elevation springs of } \\
\text { the Swiss Central Alps. Hydrobiologia DOI 10.1007/s10750-016- } \\
2918-0 \text {. } \\
\text { 2) Küry, D., V. Lubini \& P. Stucki 2016: Empfindlichkeit von Quell- } \\
\text { Lebensgemeinschaften gegenüber Klimaveränderungen in den Alpen. } \\
\text { Projekt-Schlussbericht. }\end{array}$ & Küry, Daniel \\
\hline & & $\begin{array}{l}\text { Klima- und Bestandesgeschichte im Arvenurwald God da } \\
\text { Tamangur }\end{array}$ & Not available & Stoffel, Markus \\
\hline & & $\begin{array}{l}\text { Prognostizierte Effekte des Klimawandels auf Indika- } \\
\text { torarten für strukturelle und biologische Diversität im } \\
\text { Gebirgswald }\end{array}$ & Not available & Bollmann, Kurt \\
\hline & & $\begin{array}{l}\text { Wie wirkt sich der Klimawandel auf die Verbreitung des } \\
\text { Schneehasen (Lepus timidus) in klimatisch unterschiedli- } \\
\text { chen Regionen der Schweiz aus? }\end{array}$ & Not available & Rehnus, Maik \\
\hline & & $\begin{array}{l}\text { Erdstrombewegungen und Klimamessungen am Mount } \\
\text { Chavagl (Schweizerischer Nationalpark; Dauerprojekt) }\end{array}$ & $\begin{array}{l}\text { 1) Gamper, M. 1981. Heutige Solifluktionsbeträge von Erdströmen. } \\
\text { Ergebn. der wiss. Unters. im Schweiz. Nationalpark } 79 . \\
\text { 2) Gamper, M. 1983. Controls ans retaes of movement of solifluction } \\
\text { lobes in the Eastern Swiss Alps. In: Permafrost: Fourth Internationale } \\
\text { Conference, Proceedings 328-333. } \\
\text { 3) Gamper, M. 1987. Mikroklima und Solifluktion. Resultate von Mes- } \\
\text { sungen im Schweizerischen Nationalpark in den Jahren 1975-1985. } \\
\text { 4) Gamper, M. 1981. Heutige Solifluktionsbeträge von Erdströmen } \\
\text { und klimamorphologische Interpretation fossiler Böden. Dissertation } \\
\text { Universität Zürich. } \\
\text { 5) Keller, F. 2017. Periglazialforschung im Schweizerischen Natio- } \\
\text { nalpark. Bericht über die Klima- und Erdstrommessungen am Mount } \\
\text { Chavagl von Semptember 2015 - August 2016. Wissenschaftliche } \\
\text { Nationalparkkommission. Academia Engiadina, Samedan. }\end{array}$ & Keller, Felix \\
\hline & & Klimamessnetz SNP & Not available & $\begin{array}{l}\text { Konzelmann, } \\
\text { Thomas }\end{array}$ \\
\hline & & $\begin{array}{l}\text { Waldgrenzverschiebungen zwischen } 1899 \text { und } 2008 \text { im } \\
\text { Gebiet des Schweizerischen Nationalparks (unter beson- } \\
\text { derer Berücksichtigung des Klimawandels) }\end{array}$ & $\begin{array}{l}\text { Berger, S. 2013. Waldflächenveränderungen im Schweizerischen Na- } \\
\text { tionalpark zwischen } 1899 \text { und 2008. Masterarbeit Geographisches } \\
\text { Institut Universität Basel. }\end{array}$ & $\begin{array}{l}\text { Kuhn, } \\
\text { Nikolaus Josef }\end{array}$ \\
\hline & & $\begin{array}{l}\text { Lokalklimatische Untersuchungen am Fuornbach } \\
\text { (Ova dal Fuorn) und am Spöl }\end{array}$ & $\begin{array}{l}\text { Lüdi, W. 1966. Lokalklimatische Untersuchungen am Fuornbach } \\
\text { (Ova dal Fuorn) und am Spöl. Ergebnisse der wissenschaftlichen } \\
\text { Untersuchungen im Schweizer Nationalpark } 56 .\end{array}$ & Lüdi, Walter \\
\hline & & Klimaänderung und Tourismuspotential & $\begin{array}{l}\text { Ketterer, C. 2009. Klimatisches Tourismuspotenzial des Engadins auf } \\
\text { der Grundlage von Messungen und regionalen Klimasimulationen. } \\
\text { Masterarbeit, Universität Freiburg im Breisgau }\end{array}$ & $\begin{array}{l}\text { Matzarakis, } \\
\text { Andreas }\end{array}$ \\
\hline
\end{tabular}




\begin{tabular}{|c|c|c|c|c|}
\hline Protected Area & \begin{tabular}{|l|} 
Research \\
records
\end{tabular} & Research title & Publications & \begin{tabular}{|l|} 
Principal \\
investigator
\end{tabular} \\
\hline \multirow[t]{5}{*}{ Swiss National Park } & & $\begin{array}{l}\text { Climatic and topographic effects on mortality processes of } \\
\text { mountain pine in the Swiss National Park }\end{array}$ & $\begin{array}{l}\text { 1) Bigler, C. \& A. Rigling 2013. Precision and accuracy of tree-ring- } \\
\text { based death dates of mountain pines in the Swiss National Park. } \\
\text { Trees - Structure and Function 27:1703-1712. } \\
\text { 2) Bigler, C. 2016. Trade-offs between growth rate, tree size and } \\
\text { lifespan of mountain pine (Pinus montana) in the Swiss National Park. } \\
\text { PLoS One } 11 \text { (3):e0150402. doi:10.1371/journal.pone.0150402. }\end{array}$ & Bigler, Christof \\
\hline & & $\begin{array}{l}\text { Bilan des } 8 \text { premières années du monitoring des } \\
\text { étangs de Macun (Parc National Suisse): évolution de la } \\
\text { biodiversité aquatique et relation avec le réchauffement } \\
\text { climatique }\end{array}$ & $\begin{array}{l}\text { Dalmard, A.-C. } 2011 \text {. Bilan des } 8 \text { premières années du monitor- } \\
\text { ing des étangs de Macun (Parc National Suisse): évolution de la } \\
\text { biodiversité aquatique et relation avec le réchauffement climatique. } \\
\text { HEPIA Lullier }\end{array}$ & Oertli, Beat \\
\hline & & $\begin{array}{l}\text { Geometry of the last glacial maximum (LGM) in the Swiss } \\
\text { Alps and its paleoclimatological significance }\end{array}$ & $\begin{array}{l}\text { Florineth, D. 1998. Geometry of the last glacial maximum (LGM) in } \\
\text { the Swiss Alps and its paleoclimatological significance. Dissertation, } \\
\text { Geologisches Institut Universität Bern. }\end{array}$ & $\begin{array}{l}\text { Schlüchter, } \\
\text { Christian }\end{array}$ \\
\hline & & $\begin{array}{l}\text { Climate-driven range dynamics and potential current } \\
\text { disequilibrium in Alpine vegetation }\end{array}$ & $\begin{array}{l}\text { 1) Rumpf, S. et al. 2018. Range dynamics of mountain plants de- } \\
\text { crease with elevation. In: Proceedings of the US Academy of Sciences } \\
\text { (PNAS) 115(8): 1848-1853. } \\
\text { 2) Rumpf, S.B., K. Hülber, N.E. Zimmermann \& S. Dullinger } 2017 . \\
\text { Climate-driven range dynamics and } 559 \text { potential current disequi- } \\
\text { librium in Alpine vegetation. } 6^{\text {th }} \text { Symposium for Research in Protected } \\
\text { Areas. } 2 \text { to } 3 \text { November } 2017 \text {, Faculty of Natural Sciences, University } \\
\text { of Salzburg, Austria. }\end{array}$ & $\begin{array}{l}\text { Dullinger, } \\
\text { Stefan }\end{array}$ \\
\hline & & $\begin{array}{l}\text { Lokalklimatische Untersuchungen in Waldgesel- } \\
\text { Ischaften - Microclimate of forest stands }\end{array}$ & $\begin{array}{l}\text { Pallmann, H. \& E. Frei 1943. Lokalklimate einiger Waldgesel- } \\
\text { Ischaften. Ergebn. der Wiss. Unters. im Schweiz. Nationalpark } 12 .\end{array}$ & $\begin{array}{l}\text { Pallmann, } \\
\text { Hans }\end{array}$ \\
\hline $\begin{array}{l}\text { Swiss Tectonic Arena } \\
\text { Sardona UNESCO World } \\
\text { Heritage }\end{array}$ & 1 & $\begin{array}{l}\text { ClimAlpTour - Climate change and its impact on tourism } \\
\text { in the Alpine Space. Pilotregion Heidiland/Pizol }\end{array}$ & $\begin{array}{l}\text { Clivaz, C., M. Doctor, S. Gessner, L. Ketterer, T. Luthe, M. Schuckert, } \\
\text { D. Siegrist \& R. Wyss 2012. Adaptionsstrategien des Tourismus an } \\
\text { den Klimawandel in den Alpen. Ergebnisse des alpenweiten Projekts } \\
\text { ClimAlpTour in der Schweiz. Schriftenreihe des Instituts für Landschaft } \\
\text { und Freiraum. HSR Hochschule für Technik Rapperswil 8. }\end{array}$ & $\begin{array}{l}\text { Siegrist, } \\
\text { Dominik }\end{array}$ \\
\hline \multirow[t]{3}{*}{$\begin{array}{l}\text { UNESCO Biosphere } \\
\text { Entlebuch }\end{array}$} & \multirow[t]{3}{*}{3} & $\begin{array}{l}\text { HydroServ - Vulnerability of hydrological ecosystem ser- } \\
\text { vices: integrative analysis under changes of climate and } \\
\text { socio-economy with an emphasis on adaptation }\end{array}$ & $\begin{array}{l}\text { Lietha, J. } 2011 \text {. Rivalität in der Landnutzung. Nachhaltigkeitsana- } \\
\text { lyse des institutionellen Ressourcenregimes im Skigebiet Sörenberg. } \\
\text { Masterthesis, IRL, ETH Zürich. }\end{array}$ & $\begin{array}{l}\text { Grêt-Regamey, } \\
\text { Adrienne }\end{array}$ \\
\hline & & $\begin{array}{l}\text { Moorhabitate der UNESCO Biosphäre Entlebuch im } \\
\text { Wandel des Klimas }\end{array}$ & $\begin{array}{l}\text { Sschmidt, C. et al. 2016. Moorhabitate der UNESCO Biosphäre } \\
\text { Entlebuch im Wandel des Klimas. Inter- Und transdisziplinäre Projek- } \\
\text { tarbeit Nachhaltige Entwicklung. CDE, Universität Bern. }\end{array}$ & $\begin{array}{l}\text { Hammer, } \\
\text { Thomas }\end{array}$ \\
\hline & & \begin{tabular}{|l|} 
Klimaneutrale Energieversorgung in der UNESCO \\
Biosphäre Entlebuch - Die regionale Umsetzung der Ener- \\
giestrategie 2050 mit Fokus auf die $\mathrm{CO}_{2}$-Emissionen
\end{tabular} & $\begin{array}{l}\text { Bürgi, M. 2015. Klimaneutrale Energieversorgung in der UNESCO } \\
\text { Biosphäre Entlebuch - Die regionale Umsetzung der Energiestrategie } \\
2050 \text { mit Fokus auf die } \mathrm{CO}_{2} \text {-Emissionen. Masterarbeit. FHNW, Hoch- } \\
\text { schule für Life Sciences. }\end{array}$ & $\begin{array}{l}\text { Lüscher, } \\
\text { Claude }\end{array}$ \\
\hline $\begin{array}{l}\text { UNESCO Biosphärenres- } \\
\text { ervat Engiadina Val Müstair }\end{array}$ & 1 & \begin{tabular}{|l|} 
A resurvey of millipede diversity in the Swiss National \\
Park and its surroundings: comparison of data from 1919 \\
with 2018
\end{tabular} & Not available & Baur, Bruno \\
\hline \multirow[t]{2}{*}{ Wildnispark Zurich } & \multirow{2}{*}{$\begin{array}{l}1(+1 \\
\text { elder } \\
\text { research } \\
\text { project, in } \\
\text { bold) }\end{array}$} & $\begin{array}{l}\text { Jährliche Variabilität der Frühholzgefässe: ein klimatisches } \\
\text { Signal? }\end{array}$ & Not available & Fonti, Patrick \\
\hline & & Die Klimaverhäłlnisse des Albisgebietes & $\begin{array}{l}\text { Lüdi, W. \& B. Stüssi. Die Klimaverhätlnisse des Albisgebietes. Geo- } \\
\text { botanisches Institut Zürich18. }\end{array}$ & $\begin{array}{l}\text { Schmidt, } \\
\text { Ronald }\end{array}$ \\
\hline
\end{tabular}

